\title{
Third national surveillance of risk factors of non-communicable diseases (SuRFNCD-2007) in Iran: methods and results on prevalence of diabetes, hypertension, obesity, central obesity, and dyslipidemia
}

\author{
Alireza Esteghamati*1, Alipasha Meysamie², Omid Khalilzadeh1, \\ Armin Rashidi ${ }^{1}$, Mehrdad Haghazali ${ }^{3}$, Fereshteh Asgari ${ }^{3}$, Mandana Kamgar ${ }^{1}$, \\ Mohammad Mehdi Gouya ${ }^{3}$ and Mehrshad Abbasi ${ }^{1}$
}

\begin{abstract}
Address: ${ }^{1}$ Endocrinology and Metabolism Research Center (EMRC), Vali-Asr Hospital, Tehran University of Medical Sciences, Tehran, Iran, ${ }^{2}$ Department of Community Medicine, School of Medicine, Tehran University of Medical Sciences, Tehran, Iran and ${ }^{3}$ Center for Disease Control, Ministry of Health and Medical Education, Tehran, Iran

Email: Alireza Esteghamati* - esteghamati@tums.ac.ir; Alipasha Meysamie - meysamie@tums.ac.ir; Omid Khalilzadeh - khalilzadeh@razi.tums.ac.ir; Armin Rashidi - rasidiarmin@yahoo.com; Mehrdad Haghazali - haghmehr@yahoo.com; Fereshteh Asgari - asgarifcdc@yahoo.com; Mandana Kamgar - mandanakamkar@yahoo.com; Mohammad Mehdi Gouya - mgoya57@yahoo.com; Mehrshad Abbasi - mehrshad_abbasi@yahoo.com

* Corresponding author
\end{abstract}

\section{Published: 29 May 2009}

BMC Public Health 2009, 9:167 doi:10.1 186/147/-2458-9-167
Received: 4 November 2008

Accepted: 29 May 2009

This article is available from: http://www.biomedcentral.com/I47I-2458/9/167

(C) 2009 Esteghamati et al; licensee BioMed Central Ltd.

This is an Open Access article distributed under the terms of the Creative Commons Attribution License (http://creativecommons.org/licenses/by/2.0), which permits unrestricted use, distribution, and reproduction in any medium, provided the original work is properly cited.

\begin{abstract}
Background: The burden of non-communicable diseases is rising globally. This trend seems to be faster in developing countries of the Middle East. In this study, we presented the latest prevalence rates of a number of important non-communicable diseases and their risk factors in the Iranian population.

Methods: The results of this study are extracted from the third national Surveillance of Risk Factors of Non-Communicable Diseases (SuRFNCD-2007), conducted in 2007. A total of 5,287 Iranian citizens, aged I5-64 years, were included in this survey. Interviewer-administered questionnaires were applied to collect the data of participants including the demographics, diet, physical activity, smoking, history of hypertension, and history of diabetes. Anthropometric characteristics were measured and serum biochemistry profiles were determined on venous blood samples. Diabetes (fasting plasma glucose $\geq 126 \mathrm{mg} / \mathrm{dl}$ ), hypertension (systolic blood pressure $\geq 140 \mathrm{mmHg}$, diastolic blood pressure $\geq 90 \mathrm{mmHg}$, or use of anti-hypertensive drugs), dyslipidemia (hypertriglyceridemia: triglycerides $\geq 150 \mathrm{mg} / \mathrm{dl}$, hypercholesterolemia: total cholesterol $\geq 200 \mathrm{mg} / \mathrm{dl}$ ), obesity (body mass index $\geq 30 \mathrm{~kg} / \mathrm{m}^{2}$ ), and central obesity (waist circumference $\geq 80 \mathrm{~cm}$ in females and $\geq 94 \mathrm{~cm}$ in males) were identified and the national prevalence rates were estimated.

Results: The prevalence of diabetes, hypertension, obesity, and central obesity was $8.7 \%(95 \% \mathrm{Cl}=7.4-10.2 \%), 26.6 \%(95 \% \mathrm{Cl}$ $=24.4-28.9 \%), 22.3 \%(95 \% \mathrm{Cl}=20.2-24.5 \%)$, and $53.6 \%(95 \% \mathrm{Cl}=50.4-56.8 \%)$, respectively. The prevalence of hypertriglyceridemia and hypercholesterolemia was $36.4 \%(95 \% \mathrm{Cl}=34.1-38.9 \%)$ and $42.9 \%(95 \% \mathrm{Cl}=40.4-45.4 \%)$, respectively. All of the mentioned prevalence rates were higher among females (except hypertriglyceridemia) and urban residents.

Conclusion: We documented a strikingly high prevalence of a number of chronic non-communicable diseases and their risk factors among Iranian adults. Urgent preventive interventions should be implemented to combat the growing public health problems in Iran.
\end{abstract}




\section{Background}

Chronic non-communicable diseases (NCDs) such as cardiovascular disease and diabetes are the leading cause of death worldwide [1], having comprised $60 \%$ of all deaths in 2005. Approximately $80 \%$ of NCD-attributable deaths are occurring in low and middle-income countries [2]. Furthermore, NCDs were responsible for nearly half of the burden (measured in disability-adjusted life years [DALYs]) of diseases in 2005, both worldwide and in low/ middle-income countries [3]. The global prevalence of NCDs is increasing, with the majority of cases occurring in developing countries [4]. In this context, the Middle East is expected to bear one of the world's greatest increases in the absolute burden of NCDs and their risk factors in the near future. Most of this increase is anticipated to affect the economically productive age of 45 to 64 years, in contrast to most developed countries in which the increase in chronic disease burden concerns mainly the ages above 65 years [5-7]. The increasing burden of NCDs is especially prominent among urban dwellers, and is consistent with the epidemiological transition from communicable to non-communicable chronic diseases as the predominant causes of morbidity in developing populations [8,9]. The age-standardized death rate attributable to cardiovascular diseases and diabetes is estimated to be higher than 400 per 100,000 in Iran, one of the largest populations in the Middle East. The loss of the Iranian gross domestic product (GDP) due to heart disease and diabetes in 2015 will be $167 \%$ of that in 2006 [3].

The results of the Asia-Pacific Cohort Studies Collaboration (APCSC) project have improved our insight to the prevalence of NCDs and their consequences in the AsiaPacific region [10]. Overweight and obesity are endemic problems in much of the region. The population-attributable fractions in this region because of overweight and obesity is up to $9.2 \%$ for coronary heart disease mortality, $2.9 \%$ for hemorrhagic stroke mortality, and $10.2 \%$ for ischemic stroke mortality [11]. According to the nationally representative data available from 12 countries in the region, diabetes has a prevalence of between $2.6 \%$ to $15.1 \%$. The population-attributable fractions because of diabetes is up to $12 \%$ for coronary heart disease mortality, $6 \%$ for hemorrhagic stroke mortality, and $11 \%$ for ischemic stroke mortality [12]. The prevalence of hypertension in the region is up to $47 \%$ in men and $38 \%$ in women. The population-attributable fractions for coronary heart disease mortality, hemorrhagic stroke mortality and ischemic stroke mortality in men (women) are up to $39 \%, 66 \%$ (49\%), and 44\% (45\%), respectively [13]. The prevalence of high serum total cholesterol (TC) in the region ranges from $4 \%$ to $27 \%$. Up to $14 \%$ and $15 \%$, respectively, of coronary artery disease mortality and ischemic disease mortality is attributable to high TC [14].
The results from Middle-Eastern countries are scant, mainly because of the rarity of nationally representative data in these countries. In order to determine the magnitude of the problem associated with NCDs in the population of Iran, the national surveys of NCDs risk factors have been conducted annually since 2005 under the supervision and recommendations of the World Health Organization (WHO). The first, second and the third surveys were performed in 2005, 2006 and 2007. The third national Surveillance of Risk Factors of Non-Communicable Diseases (SuRFNCD) provided the demographic, anthropometric and biochemical characteristics of a nationally representative sample of 5,278 Iranian adults aged 15-64 as well as valuable information on their diet and physical activity. In this study, we aimed to describe the methodology applied to conduct this survey and to present the national prevalence of a number of important non-communicable health problems and their risk factors including diabetes, hypertension, obesity, central obesity, and dyslipidemia.

\section{Methods}

The third national SuRFNCD was conducted in March 2007 and comprised 5,287 non-institutionalized Iranian adults aged 15-64 years. Institutionalized individuals such as soldiers and those living in nursing homes were not included. After excluding participants aged 15 to 24 years $(n=1,054)$, analysis was performed on data of the remaining 4,233 individuals, who were aged 25-64 years. The reason for this exclusion was related to the relatively rapidly changing BMI of individuals between 15 and 24 years of age. The appropriate method to define obesity in this age group is by using percentiles in which case comparisons with adult obesity would not be trivial and may negatively affect the results.

The study was designed based on the STEPwise guidelines of the WHO [15]. The survey received ethics approval of the Center for Disease Control (CDC) of Iran and was carried out in collaboration with 40 medical schools across the country. All participants gave verbal informed consent. The participants were recruited in clusters of 10 males and 10 females living in neighboring households. The address of the first subject in each cluster was selected randomly out of the postal addresses and sampling was continued based on a predetermined schedule to register all 20 participants. The target population was adults aged 15 to 64 years, classified into 5 ten-year age groups (i.e. 15-24, 25-34, 35-44, 45-54, and 55-64). Each cluster comprised two males and two females in each age group. The number of clusters selected from each province was proportional to the urban/rural size of that province. For example, 51 clusters were taken from Tehran and only 2 from Ilam (the smallest of the 30 provinces of Iran). The 
participants were visited at their household by interviewers who were recommended by the collaborating medical schools to the managerial team in CDC. Interviewers were trained and instructed on the details of the survey in a one-day workshop in Tehran prior to the commencement of the survey. Informed consents were obtained and the required information was recorded in the following three steps. In step 1, general health characteristics and demographic information were collected by standardized questionnaires. In step 2, physical examination was performed to determine weight, height, waist circumference, and blood pressure. Participants were subsequently invited to prepare for step 3, i.e. collection of 10-12 hour fasting blood samples.

\section{Step I: Demographic Data and Behavioral Assessments} Interviewer-administered questionnaires based on WHO STEPS instrument (core and expanded) were filled out in 6 different domains: demographic information, diet, physical activity, tobacco use, history of hypertension, and history of diabetes. Demographic information was comprised of insurance coverage and occupation in addition to sex, age, province of residence, residential area (urban/rural) and the postal address.

To identify participants with known diabetes mellitus (KDM), they were asked if a health care professional had ever told them that they had diabetes. History of diabetes in the first degree relatives was also recorded. For determination of access to care, participants were asked whether a health care professional has told them to have diabetes during the past 12 month, and whether they have had a blood glucose test during the past 12 months. Diabetic individuals were further asked whether their physician had recommended life style and nutrition modification, or had prescribed insulin and/or oral agents for them.

Regarding the history of hypertension, consumption of anti-hypertensive medication in the past 2 weeks, the time of the most recent blood pressure measurement by a health care professional, and whether a health care professional has ever told the participant to have hypertension were recorded.

\section{Step 2: Physical Examination}

Weight and height of participants were determined in light clothing and without shoes. Portable calibrated electronic weighing scale and portable measuring inflexible bars were used. Waist circumference (WC) was measured using constant tension tape at the end of a normal expiration, with arms relaxed at the sides, at the midpoint between the lower part of the lowest rib and the highest point of the hip on the mid-axillary line. Blood pressure was measured with a calibrated Omron M7 sphygmomanometer (HEM-780-E). The average of three measure- ments, made at intervals of 5 minutes, was used for analysis.

\section{Step 3: Biochemical Measurements}

$10 \mathrm{ml}$ of venous blood was taken in sitting position, collected in 4 tubes, centrifuged immediately, and transferred under cold chain condition to the Central Reference Laboratory of Ministry of Health of Iran (Tehran, Iran). Fasting plasma glucose (FPG), total cholesterol (TC), high density lipoprotein cholesterol (HDL-C), low density lipoprotein cholesterol (LDL-C) and triglycerides (TG) were measured. One tube was treated with $2 \mu \mathrm{g}$ sodium fluoride for glucose preservation to enhance the accuracy of glucose measurement. FPG was measured by the enzymatic colorimetric method using glucose oxidize test (intra- and inter-assay coefficients of variation $2.1 \%$ and 2.6\%, respectively). Serum TC, TG, LDL-C and HDL-C were determined by enzymatic methods (Parsazmun, Karaj, Iran). The two remaining tubes were transferred to the endocrine laboratory of Vali-Asr hospital (Tehran University of Medical sciences, Tehran, Iran) for insulin, C reactive protein, and leptin measurements, which are not the subjects of this report.

\section{Definition of variables}

We designated participants as having known diabetes mellitus (KDM) if a health care professional had ever told them to have diabetes. In those without KDM, FPG $=126$ $\mathrm{mg} / \mathrm{dl}$ was regarded as newly diagnosed diabetes. Impaired fasting glucose (IFG) was defined in those without KDM by FPG levels $\geq 100 \mathrm{mg} / \mathrm{dl}$ ( $5.6 \mathrm{mmol} / \mathrm{l}$ ) but < $126 \mathrm{mg} / \mathrm{dl}$ (7.0 mmol/l) [16]. Hypertension was defined as systolic blood pressure $\geq 140 \mathrm{mmHg}$, diastolic blood pressure $\geq 90 \mathrm{mmHg}$, or current use of anti-hypertensive drugs. Pre-hypertension was defined as $120 \mathrm{~mm} \mathrm{Hg} \geq$ systolic blood pressure $<140 \mathrm{mmHg}$ or $80 \mathrm{mmHg} \leq$ diastolic blood pressure $<90 \mathrm{mmHg}$ in non-hypertensive participants [17]. The body mass index (BMI; calculated as weight $/$ height $^{2}$ ) $\geq 30 \mathrm{~kg} / \mathrm{m}^{2}$ and $25 \leq \mathrm{BMI}<30 \mathrm{~kg} / \mathrm{m}^{2}$ were regarded respectively as obesity and overweight [18]. Central obesity was defined by the International Diabetes Federation (IDF) criteria (WC $\geq 80 \mathrm{~cm}$ in females and $\geq 94 \mathrm{~cm}$ in males) [19] and the criteria set by the National Cholesterol Education Program-Third Adult Treatment Panel (ATP III) criteria (WC $\geq 88 \mathrm{~cm}$ in females and $\geq 102 \mathrm{~cm}$ in males) [20]. For high TC, the cut points of $200 \mathrm{mg} / \mathrm{dl}$ and $240 \mathrm{mg} / \mathrm{dl}$ were considered. High TG was defined as TG $\geq$ $150 \mathrm{mg} / \mathrm{dl}[19]$.

\section{Statistical analysis}

Complex sample survey analysis was performed in SPSS 16 for Windows (Chicago, IL, USA). To extrapolate the results to the Iranian adult population, the data were weighted for age (10-year strata), sex, and residence area (rural/urban) according to the results of the national cen- 
sus of Iran in 2006 ( $\mathrm{n}=31,409,737$, age: $25-64$ years [21]). The complex sample analysis plan was defined based on the clusters of sampling protocol, strata (age groups, sex, and residential area) and the determined weights. National estimates, made in the complex survey analysis mode, are expressed as mean \pm standard error of the mean (SEM) or prevalence $(95 \% \mathrm{CI})$.

\section{Results}

Since the questionnaires were filled out by interviewers, missing data were extremely rare. For biochemical measurements, however, 836 (19.7\%) participants did not consent to blood sampling. Biochemical measurements were thus available for the remaining 3,397 individuals. As presented in Table 1, the total prevalence of diabetes was estimated to be $8.7 \%(95 \% \mathrm{CI}=7.4-10.2)$, about half (47.1\%) of which can be attributed to newly diagnosed disease. The prevalence of diabetes was higher among older age groups, females, and urban dwellers. The prevalence of IFG was $9.2 \%$ among non-diabetic individuals.

The national estimate of BMI was $26.47 \pm 0.15 \mathrm{~kg} / \mathrm{m}^{2}$. The prevalence of obesity and overweight was $22.3 \%$ (95\%CI
$=20.2-24.5)$ and $36.3 \%(95 \% \mathrm{CI}=34.6-38.1)$, respectively. Obesity was more prevalent among females and urban dwellers (Table 2). The mean WC of Iranian adults was estimated to be $88.67 \pm 0.38 \mathrm{~cm}$. The prevalence of central obesity, defined by the ATP III and IDF criteria, were respectively $33.8 \%$ (54.4\% in females and $13.9 \%$ in males) and $53.6 \%(73.4 \%$ in females and $34.4 \%$ in males) (Table 3). Irrespective of the criteria used, the prevalence of central obesity grew with increasing age, and was higher among females and urban residents.

The estimated systolic and diastolic blood pressure was $122.84 \pm 0.57 \mathrm{mmHg}$ and $80.67 \pm 0.39 \mathrm{mmHg}$, respectively. Overall 26.6\% $(95 \% \mathrm{CI}=24.4-28.9)$ of Iranian adults were estimated to be hypertensive and an additional $38.2 \%(95 \% \mathrm{CI}=36.1-40.2$; corresponding to 12 million people) to have prehypertension. Hypertension was more prevalent among older age groups, females and urban residents (Table 4 ).

The national estimates of TG and TC were $148.83 \pm 2.45$ $\mathrm{mg} / \mathrm{dl}$ and $195.63 \pm 1.10 \mathrm{mg} / \mathrm{dl}$, respectively. The prevalence of hypertriglyceridemia, TC $\geq 200 \mathrm{mg} / \mathrm{dl}$, and TC $\geq$

Table I: Estimates of prevalence of newly diagnosed diabetes, known diabetes and IFG among Iranian adults 25-64 years old

\begin{tabular}{|c|c|c|c|c|c|c|c|c|}
\hline & \multicolumn{2}{|c|}{ Impaired Fasting Glucose ${ }^{a b}$} & \multicolumn{2}{|c|}{ Known DM } & \multicolumn{2}{|c|}{ New DMa } & \multicolumn{2}{|c|}{ New and Known DMa } \\
\hline & $\begin{array}{l}\text { National } \\
\text { estimate }^{c}\end{array}$ & $\begin{array}{c}\text { Prevalence } \\
\text { (95\% CI) }\end{array}$ & $\begin{array}{l}\text { National } \\
\text { estimate }^{c}\end{array}$ & $\begin{array}{c}\text { Prevalence } \\
(95 \% \mathrm{Cl})\end{array}$ & $\begin{array}{l}\text { National } \\
\text { estimate }^{c}\end{array}$ & $\begin{array}{c}\text { Prevalence } \\
(95 \% \mathrm{Cl})\end{array}$ & $\begin{array}{l}\text { National } \\
\text { estimate }^{c}\end{array}$ & $\begin{array}{c}\text { Prevalence } \\
(95 \% \mathrm{Cl})\end{array}$ \\
\hline \multicolumn{9}{|l|}{ Age } \\
\hline $\begin{array}{l}25-34 \\
(\mathrm{n}=843)\end{array}$ & 0.6 & $5.1(3.4-7.6)$ & 0.1 & $0.7(0.3-1.5)$ & 0.3 & $2.5(1.4-4.4)$ & 0.4 & $3.2(2.0-5.0)$ \\
\hline $\begin{array}{l}35-44 \\
(n=902)\end{array}$ & 0.9 & $\begin{array}{c}10.0 \\
(7.6-13.0)\end{array}$ & 0.4 & $4.9(3.3-7.3)$ & 0.4 & $4.3(3.2-5.8)$ & 0.8 & $9.2(7.0-12.1)$ \\
\hline $\begin{array}{l}45-54 \\
(n=869)\end{array}$ & 0.9 & $\begin{array}{c}13.6 \\
(11.5-16.1)\end{array}$ & 0.5 & $8.4(6.7-10.4)$ & 0.4 & $5.6(3.5-8.7)$ & 0.9 & $\begin{array}{c}14.0 \\
(11.2-17.3)\end{array}$ \\
\hline $\begin{array}{l}55-64 \\
(n=783)\end{array}$ & 0.5 & $\begin{array}{c}14.6 \\
(11.9-17.9)\end{array}$ & 0.4 & $\begin{array}{c}12.1 \\
(8.2-17.4)\end{array}$ & 0.2 & $6.7(4.9-9.1)$ & 0.6 & $\begin{array}{c}18.8 \\
(14.7-23.6)\end{array}$ \\
\hline \multicolumn{9}{|l|}{ Sex } \\
\hline $\begin{array}{l}\text { Males } \\
(\mathrm{n}=1645)\end{array}$ & 1.5 & $9.3(7.7-11.3)$ & 0.7 & $4.4(3.1-6.1)$ & 0.6 & $4.0(3.1-5.2)$ & 1.3 & $8.4(6.6-10.5)$ \\
\hline $\begin{array}{l}\text { Females } \\
(\mathrm{n}=1752)\end{array}$ & 1.4 & $9.0(7.2-11.3)$ & 0.8 & $4.9(3.8-6.2)$ & 0.7 & $4.2(2.9-6.0)$ & 1.4 & $9.1(7.4-11.2)$ \\
\hline \multicolumn{9}{|l|}{$\begin{array}{l}\text { Residential } \\
\text { area }\end{array}$} \\
\hline $\begin{array}{l}\text { Urban } \\
(n=2175)\end{array}$ & 2.1 & $9.8(8.3-11.4)$ & 1.1 & $4.9(3.9-6.2)$ & 1.0 & $4.3(3.4-5.4)$ & 2.1 & $9.2(7.8-10.9)$ \\
\hline $\begin{array}{l}\text { Rural } \\
(n=1222)\end{array}$ & 0.7 & $7.8(5.4-11.1)$ & 0.3 & $3.9(2.4-6.1)$ & 0.3 & $3.7(2.1-6.3)$ & 0.7 & $7.5(5.2-10.9)$ \\
\hline $\begin{array}{l}\text { Total } \\
\text { national } \\
\text { estimate } \\
(\mathrm{n}=3397)\end{array}$ & 2.9 & $9.2(7.9-10.7)$ & 1.5 & $4.6(3.8-5.7)$ & 1.3 & $4.1(3.3-5.1)$ & 2.7 & $8.7(7.4-10.2)$ \\
\hline
\end{tabular}

DM: Diabetes mellitus, $\mathrm{Cl}$ : confidence interval

a In subjects with valid fasting plasma glucose measurements

$\mathrm{b}$ In non-diabetic subjects

c Rounded to the nearest million

Estimates are weighted for age, sex, and residential area on the basis of the population of Iran in 2006 
Table 2: Estimates of prevalence of obesity among Iranian adults 25-64 years old

\begin{tabular}{|c|c|c|c|c|}
\hline & \multicolumn{2}{|c|}{ Obesity } & \multicolumn{2}{|c|}{ Overweight ${ }^{\mathrm{a}}$} \\
\hline & $\begin{array}{l}\text { National } \\
\text { estimate }^{b}\end{array}$ & $\begin{array}{l}\text { Prevalence } \\
(95 \% \mathrm{Cl})\end{array}$ & $\begin{array}{l}\text { National } \\
\text { estimate }^{b}\end{array}$ & $\begin{array}{l}\text { Prevalence } \\
(95 \% \mathrm{CI})\end{array}$ \\
\hline \multicolumn{5}{|l|}{ Age } \\
\hline $25-34(n=1081)$ & 1.8 & $14.4(1 \mid .5-17.8)$ & 4.1 & $31.8(29.0-34.7)$ \\
\hline $35-44(n=1113)$ & 2.4 & $26.7(22.7-31.1)$ & 3.5 & $39.4(36.1-42.8)$ \\
\hline $45-54(n=1069)$ & 1.8 & $29.3(25.6-33.2)$ & 2.5 & $39.8(36.4-43.3)$ \\
\hline $55-64(n=970)$ & 0.9 & $27.4(24.1-31.0)$ & 1.3 & $39.3(35.1-43.6)$ \\
\hline \multicolumn{5}{|l|}{ Sex } \\
\hline Males $(n=2121)$ & 2.3 & $14.2(12.2-16.5)$ & 6.0 & $37.5(35.0-40.1)$ \\
\hline Females $(n=2|| 2)$ & 4.7 & $30.6(27.3-34.0)$ & 5.4 & $35.1(32.8-37.6)$ \\
\hline \multicolumn{5}{|l|}{ Residential area } \\
\hline Urban $(n=2853)$ & 5.3 & $23.8(21.5-26.2)$ & 8.6 & $38.2(36.2-40.2)$ \\
\hline Rural $(n=1380)$ & 1.7 & $18.5(14.5-23.4)$ & 2.8 & $31.7(28.4-35.3)$ \\
\hline $\begin{array}{l}\text { Total national estimate } \\
(n=4233)\end{array}$ & 7.0 & $22.3(20.2-24.5)$ & 11.4 & $36.3(34.6-38.1)$ \\
\hline
\end{tabular}

Cl: confidence interval

a In non-obese subjects

b Rounded to the nearest million

Estimates are weighted for age, sex, and residential area on the basis of the population of Iran in 2006

$240 \mathrm{mg} / \mathrm{dl}$ were $36.4 \%(95 \% \mathrm{CI}=34.1-38.9), 42.9 \%$ $(95 \% \mathrm{CI}=40.4-45.4)$, and $14.1 \%(95 \% \mathrm{CI}=12.6-15.9)$, respectively. Dyslipidemia was more common among urban dwellers and older age groups. Females had a higher prevalence of hypercholesterolemia while males had a higher prevalence of hypertriglyceridemia (Table 5).

\section{Discussion}

The WHO STEPS surveillance program was designed to generate validated and internationally comparable data about the chronic non-communicable or cardiovascular diseases particularly for populations with less available evidences. Our third national SuRFNCD was conducted in 2007 based on the WHO STEPS guidelines. The main results of this survey indicate the high prevalence of diabetes, hypertension, obesity, central obesity, and dyslipidemia in Iran. Overall these problems were more common among females, older age groups, and in urban areas. In a large study (age: 15-64 years) in the North-East of Iran, sociodemographic factors such as progressive urbanization and advancing age were significantly correlated to the increasing prevalence of type 2 diabetes [22].

Table 3: Estimates of prevalence of central obesity defined by the ATP III and the IDF criteria among iranian adults 25-64 years old

\begin{tabular}{|c|c|c|c|c|}
\hline & \multicolumn{2}{|c|}{ High WC by IDFa } & \multicolumn{2}{|c|}{ High WC by ATPIII } \\
\hline & $\begin{array}{l}\text { National } \\
\text { estimate }^{b}\end{array}$ & $\begin{array}{l}\text { Prevalence } \\
(95 \% \mathrm{CI})\end{array}$ & $\begin{array}{l}\text { National } \\
\text { estimate }^{b}\end{array}$ & $\begin{array}{l}\text { Prevalence } \\
(95 \% \mathrm{CI})\end{array}$ \\
\hline \multicolumn{5}{|l|}{ Age } \\
\hline $25-34(n=108 I)$ & 5.0 & $39.3(34.2-44.6)$ & 2.7 & $21.5(17.5-26.1)$ \\
\hline $35-44(n=1113)$ & 5.3 & $58.7(53.7-63.5)$ & 3.3 & $37.5(31.8-43.5)$ \\
\hline $45-54(n=1069)$ & 4.2 & $66.7(61.2-71.8)$ & 2.9 & $45.5(39.0-52.2)$ \\
\hline $55-64(n=970)$ & 2.3 & $70.0(64.7-74.7)$ & 1.7 & $49.5(42.6-56.5)$ \\
\hline \multicolumn{5}{|l|}{ Sex } \\
\hline Males $(n=2|2|)$ & 5.5 & $34.4(31.3-37.5)$ & 2.2 & $13.9(11.9-16.0)$ \\
\hline Females $(n=2 \mid 12)$ & I.I & $73.4(69.5-77.0)$ & 8.4 & $54.4(50.0-58.8)$ \\
\hline \multicolumn{5}{|l|}{ Residential area } \\
\hline Urban $(n=2853)$ & 12.6 & $56.0(52.5-59.5)$ & 8.0 & $35.5(32.0-39.1)$ \\
\hline Rural $(n=1380)$ & 4.2 & $47.5(40.7-54.4)$ & 2.7 & $29.8(23.8-36.5)$ \\
\hline $\begin{array}{l}\text { Total national estimate } \\
(n=4233)\end{array}$ & 16.8 & $53.6(50.4-56.8)$ & 10.6 & $33.8(30.8-37.1)$ \\
\hline
\end{tabular}

WC: waist circumference, $\mathrm{Cl}$ : confidence interval

a ATP III: Third Adult Treatment Panel; IDF: International Diabetes Federation

b Rounded to the nearest million

Estimates are weighted for age, sex, and residential area on the basis of the population of Iran in 2006 
Table 4: Estimates of prevalence of hypertension and pre-hypertension among iranian adults 25-64 years old

\begin{tabular}{|c|c|c|c|c|}
\hline & \multicolumn{2}{|c|}{ Pre-hypertension ${ }^{\mathrm{a}}$} & \multicolumn{2}{|c|}{ Hypertension } \\
\hline & $\begin{array}{l}\text { National } \\
\text { estimate }^{b}\end{array}$ & $\begin{array}{l}\text { Prevalence } \\
(95 \% \mathrm{Cl})\end{array}$ & $\begin{array}{l}\text { National } \\
\text { estimate }^{b}\end{array}$ & $\begin{array}{l}\text { Prevalence } \\
(95 \% \mathrm{CI})\end{array}$ \\
\hline \multicolumn{5}{|l|}{ Age } \\
\hline $25-34(n=1081)$ & 5.0 & $39.0(35.3-42.8)$ & 1.8 & $14.0(\mid 1.5-17.0)$ \\
\hline $35-44(n=1113)$ & 3.6 & $39.8(36.1-43.7)$ & 2.3 & $25.2(22.6-28.1)$ \\
\hline $45-54(n=1069)$ & 2.5 & $39.1(35.9-42.4)$ & 2.4 & $38.4(35.0-41.9)$ \\
\hline $55-64(n=970)$ & 1.0 & $28.7(25.5-32.0)$ & 1.9 & $56.4(52.4-60.3)$ \\
\hline \multicolumn{5}{|l|}{ Sex } \\
\hline Males $(n=2121)$ & 7.1 & $44.3(4 I .3-47.3)$ & 3.9 & $24.7(22.1-27.4)$ \\
\hline Females $(n=2|| 2)$ & 4.9 & $31.9(29.4-34.4)$ & 4.4 & $28.6(25.1-32.3)$ \\
\hline \multicolumn{5}{|l|}{ Residential area } \\
\hline Urban $(n=2853)$ & 8.6 & $38.0(35.7-40.4)$ & 6.3 & $28.2(25.7-30.9)$ \\
\hline Rural $(n=1380)$ & 3.4 & $38.4(34.4-42.6)$ & 2.0 & $22.6(18.6-27.1)$ \\
\hline $\begin{array}{l}\text { Total national estimate } \\
(n=4233)\end{array}$ & 12.0 & $38.2(36.1-40.2)$ & 8.4 & $26.6(24.4-28.9)$ \\
\hline
\end{tabular}

$\mathrm{Cl}$ : confidence interval

a In non-hypertension subjects

$\mathrm{b}$ Rounded to the nearest million

Estimates are weighted for age, sex, and residential area on the basis of the population of Iran in 2006

Similarly, the prevalence of diabetes was linked to urbanization in a recent study (age $>19$ years) in central Iran [23]. Hypertension was significantly more common among females than males in another large study (age > 19 years) in central Iran [24]. Speedy urbanization and advancing age are not the only reasons underlying the increasing prevalence of NCDs in Iran. Nutritionallyrelated health patterns have changed dramatically in the Middle-East during recent years, partly because of social development in the absence of steady economic growth. Changes in dietary and physical activity patterns as well as inequality in health care are other important factors [25]. In the following sections, our findings are discussed and compared to the reports from the United States, western European countries, our Asian neighbors, and other Asian countries.

\section{Diabetes}

The APCSC study reports prevalence rates between 2.6\% and $15.1 \%$ for countries in the Asia-Pacific region [12]. We have previously reported the national prevalence of diabetes as $7.7 \%$ (8.3\% in females and $7.1 \%$ in males, age:

Table 5: Estimates of prevalence of high triglycerides levels and hypercholesterolemia among Iranian adults 25-64 years old

\begin{tabular}{|c|c|c|c|c|c|c|}
\hline & \multicolumn{2}{|c|}{ Triglycerides $\geq 150 \mathrm{mg} / \mathrm{dl}$} & \multicolumn{2}{|c|}{ Cholesterol $\geq 200 \mathrm{mg} / \mathrm{dl}$} & \multicolumn{2}{|c|}{ Cholesterol $\geq 240 \mathrm{mg} / \mathrm{dl}$} \\
\hline & $\begin{array}{l}\text { National } \\
\text { estimate }^{\mathrm{a}}\end{array}$ & $\begin{array}{l}\text { Prevalence } \\
(95 \% \mathrm{Cl})\end{array}$ & $\begin{array}{l}\text { National } \\
\text { estimate }^{\mathrm{a}}\end{array}$ & $\begin{array}{l}\text { Prevalence } \\
(95 \% \mathrm{Cl})\end{array}$ & $\begin{array}{l}\text { National } \\
\text { estimate }^{\mathrm{a}}\end{array}$ & $\begin{array}{l}\text { Prevalence } \\
(95 \% \mathrm{CI})\end{array}$ \\
\hline \multicolumn{7}{|l|}{ Age } \\
\hline $25-34(n=843)$ & 3.5 & $27.1(23.7-30.7)$ & 3.9 & $30.2(26.8-33.7)$ & I.I & $8.8(6.6-11.6)$ \\
\hline $35-44(n=902)$ & 3.8 & $42.4(37.4-47.7)$ & 4.2 & $46.2(42.5-50.0)$ & 1.3 & $14.2(11.4-17.6)$ \\
\hline $45-54(n=869)$ & 2.7 & $42.6(39.3-45.9)$ & 3.4 & $54.0(50.3-57.7)$ & 1.2 & $19.0(16.6-21.6)$ \\
\hline $55-64(n=783)$ & 1.5 & $44.5(40.7-48.4)$ & 2.1 & $61.6(56.3-66.6)$ & 0.8 & $25.4(21.7-29.5)$ \\
\hline \multicolumn{7}{|l|}{ Sex } \\
\hline Males $(n=1645)$ & 6.3 & $39.6(36.0-43.3)$ & 6.4 & $40.4(36.8-44.2)$ & 1.8 & $11.0(9.0-13.4)$ \\
\hline Females $(n=1752)$ & 5.1 & $33.2(30.3-36.2)$ & 7.0 & $45.4(42.1-48.7)$ & 2.7 & $17.3(15.1-19.8)$ \\
\hline \multicolumn{7}{|l|}{ Residential area } \\
\hline Urban $(n=2175)$ & 8.8 & $39.3(36.4-42.2)$ & 9.9 & $44.2(4 \mid .4-47.0)$ & 3.2 & $14.4(12.7-16.4)$ \\
\hline Rural $(n=1222)$ & 2.6 & $29.3(26.1-32.8)$ & 3.5 & $39.6(34.7-44.6)$ & 1.2 & $13.4(10.3-17.3)$ \\
\hline $\begin{array}{l}\text { Total national estimate } \\
(\mathrm{n}=3397)\end{array}$ & 11.4 & $36.4(34.1-38.9)$ & 13.5 & $42.9(40.4-45.4)$ & 4.4 & I4.I (12.6-15.9) \\
\hline
\end{tabular}

$\mathrm{Cl}$ : confidence interval

a Rounded to the nearest million

Estimates are weighted for age, sex, and residential area on the basis of the population of Iran in 2006 Iran 
25-64 years) in 2005 [26]. According to the results of the present study, the prevalence of diabetes is about $8.7 \%$ in Iranians aged $25-64$ years old $(9.2 \%$ in females and $7.5 \%$ in males). A comparison between years 2005 and 2007 can be found in Figure 1. These estimates are a just below the reported rates from the United States $(9.3 \% ; 8.2 \%$ in females and $10.6 \%$ in males, age $>20$ years) [27], but considerably higher than the estimates made in the UK (3.4\%; age: 30-59 years) [28] and comparable to reports from Australia $(7.4 \% ; 6.8 \%$ in females and $8.0 \%$ in males, age range $\geq 25$ years) [29]. The prevalence of diabetes in one of our neighbors, Turkey ( $11 \%$ in both females and males, age $\geq 35$ years) [30], is similar to our prevalence rates (12.5\%; $13.0 \%$ in females and $12.1 \%$ in males) in the same age range. Our prevalence rates are higher than those reported from China (5.5\%; $5.8 \%$ in females and $5.2 \%$ in males, age: $35-74$ years) [31] and comparable to the rates reported from Korea (7.6\%; 7.5\% in females and $8.1 \%$ in males, age $\geq 20$ years) [32]. A higher prevalence is reported in India (12.1\%, age $\geq 20$ years) [33]. The rising prevalence of diabetes with increasing age in our study is consistent with the mentioned reports. The total prevalence of diabetes estimated in our study corresponds to more than 2.7 million adults, about half of whom are newly diagnosed cases. We further estimated that approximately 2.9 million non-diabetic Iranian adults suffer from IFG.

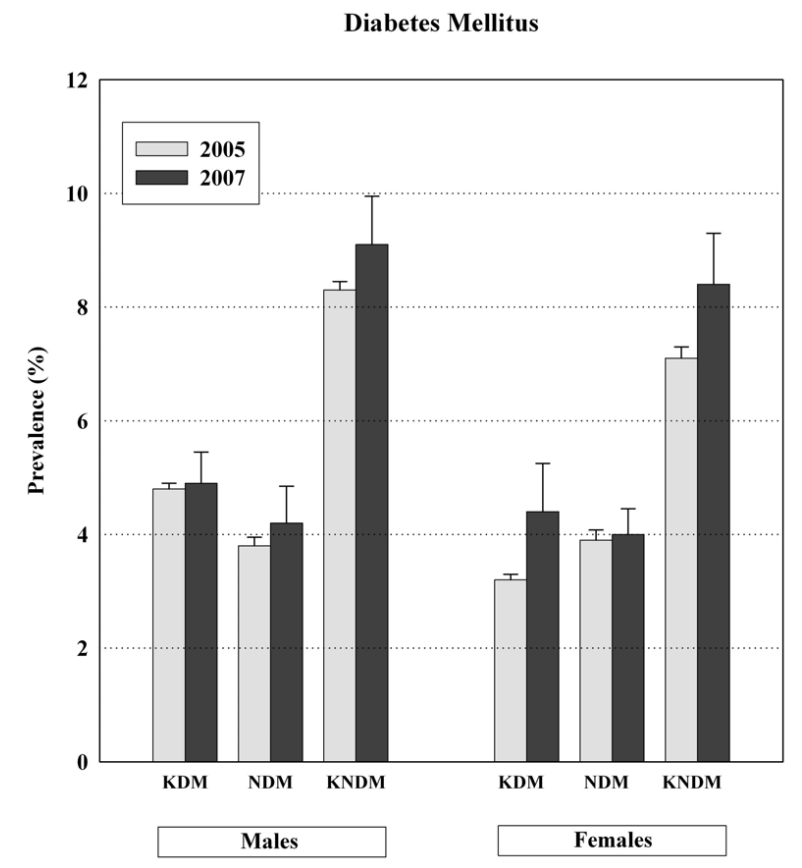

Figure I

Comparison between 2005 and 2007 in prevalence of diabetes among Iranian adults. KDM: known diabetes mellitus, NDM: newly diagnosed diabetes mellitus, KNDM: known and new diabetes mellitus.

\section{Obesity}

The APCSC study reports prevalence rates ranging from less than $1 \%$ to higher than $20 \%$ for countries in the AsiaPacific region [11]. Our study demonstrated the prevalence of obesity to be $22.3 \%$ among Iranian adults $(30.6 \%$ in females and $14.2 \%$ in males), corresponding to about 7 million individuals. A review in 2005 estimated the prevalence of obesity among urban Iranians aged 15-70 years to be between $22 \%$ and $40 \%$ [34]. Another survey (2004; age: $20-70$ years) in the north of Iran reached an estimate of $27.8 \%$ in females and $9.9 \%$ in males [35]. According to National Health and Nutrition Examination Survey (NHANES) of the US, the prevalence of obesity in individuals aged $20-74$ years was $34 \%$ in females and $31.7 \%$ in males [36]. The corresponding figures in Australia (age $\geq 25$ years) were $19 \%$ and $17 \%$, respectively [37]. In the UK, the prevalence of obesity was estimated to be $24.2 \%$ in females and $23.7 \%$ in males (national Health Survey, 2006) [38]. Compared to the results from the US and UK, the prevalence of obesity among Iranian males is much lower. The higher prevalence of obesity in Iranian females, compared to males, is in agreement with the results from most of our neighboring Arab countries, including Saudi Arabia (24\% in females and $16 \%$ in males, age $\geq 15$ years) [39], Oman (23.8\% in females and $16.7 \%$ in males, age $\geq 20$ years) [ 40 ] and Lebanon ( $18.8 \%$ in females and $14.3 \%$ in males, age $\geq 20$ years) [41]. In Turkey as well, the prevalence of obesity is higher in females ( $24.6 \%$ vs. $14.4 \%$ in males, age $\geq 20$ years) [ 42 ]. Taken together, the prevalence of obesity among Iranian females exceeds the rates in females from our neighboring countries.

\section{Central Obesity}

Approximately, 33.8\% (54.4\% in females and 13.9\% in males, corresponding to more than 10.6 million adults) of Iranian adult population are centrally obese according to ATP III definition. A unique finding of our study is the strikingly higher prevalence of central obesity among females (about 4 times more than males) compared to males. A similar ratio (46.2\% in females and $10.6 \%$ in males, age: $20-70$ years) was obtained in 2004 in a survey in the north of Iran [35]. The prevalence of ATP IIIdefined central obesity was about $38.6 \%(46.3 \%$ in females and $29.8 \%$ in males) in the US [43] and $36.5 \%$ ( $41 \%$ in females and $32 \%$ in males) in the UK [38]. In comparison, central obesity is more common in Iranian females, and considerably less common in males. The prevalence of central obesity among females in Turkey (57.6\%), one of our neighbors, is comparable to our estimate. The total prevalence of central obesity $(40.9 \%)$ and the prevalence in males (21.2\%) in Turkey (age $\geq 20$ years) are higher than our estimates for Iran [44]. The prevalence among Tunisian males $(8.8 \%)$ is lower than our estimate (age $\geq 20$ years) [45]. Finally, central obesity 
is significantly less common in the Eastern Asian countries such as China [46] and Korea [47] than in Iran.

\section{Hypertension}

The APCSC study reports prevalence rates between 5\% and $47 \%$ in men and between $7 \%$ and $38 \%$ in women for countries in the Asia-Pacific region [13]. In our survey the prevalence rate of hypertension was $26.6 \%$ (28.6\% in females and $24.7 \%$ in males), corresponding to 8.3 million adults. Our previous national estimate (2005) for the prevalence of hypertension was $25.2 \%$ (24.8\% in females and $25.5 \%$ in males) [48]. A comparison between years 2005 and 2007 is provided in Figure 2. A systematic review in 2004 showed that the prevalence of hypertension varies greatly around the world, lowest in rural India (6.8\% in females and $3.4 \%$ in males) and highest in Poland $(72.5 \%$ in females and $68.9 \%$ in males) [49]. In Turkey, the prevalence is $31.8 \%$ (36.1\% in females and $27.5 \%$ in males, age $\geq 18$ years) [50], which is higher than our estimate. The prevalence in the 35-64 year old population of the US $(27.8 \% ; 25.8 \%$ in females and $29.8 \%$ in males) was lower than our estimate in a similar age range (35.3\%; $40.1 \%$ in females and $30.7 \%$ in males), whereas reports from the UK $(41.7 \% ; 36.5 \%$ in females and $46.9 \%$ in males), Germany (55.3\%; $50.3 \%$ in females and $60.2 \%$ in males) and Spain (46.8\%; $44.6 \%$ in females and $49.0 \%$ in males) point to prevalence rates higher than our estimate [51]. The prevalence of hypertension in China in $2000-2001(27.2 \% ; 25.8 \%$ in females and $28.6 \%$ in

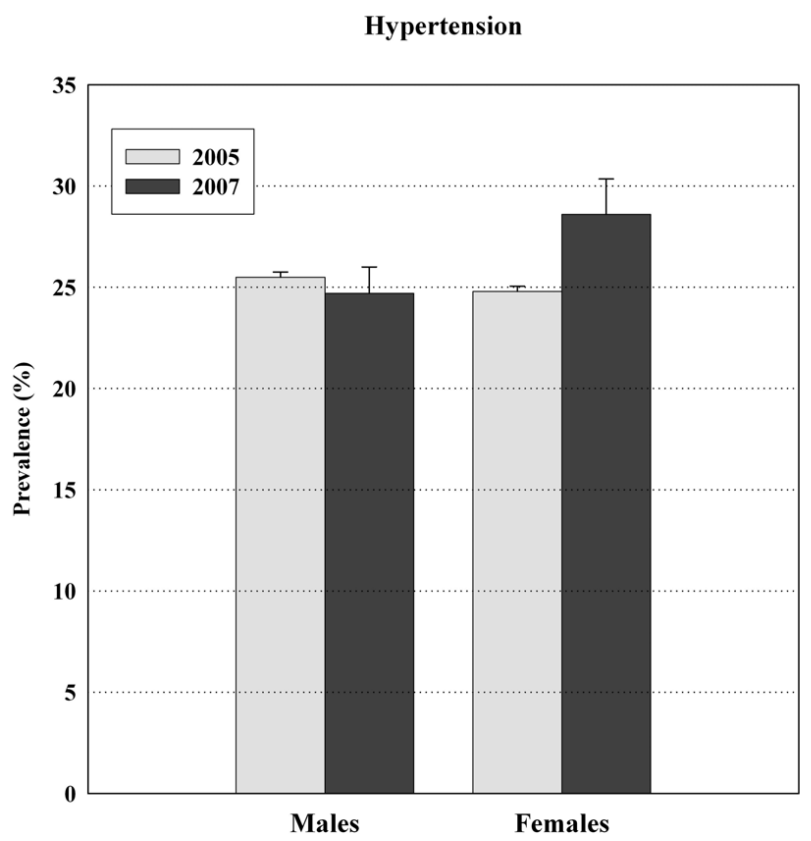

Figure 2

Comparison between 2005 and 2007 in prevalence of hypertension among Iranian adults. males, age: 35-74 years) [52] was similar to our current estimate. According to the mentioned studies, hypertension grows in prevalence with increasing age.

\section{Hypertriglyceridemia}

Data from previous reports on the prevalence of hypertriglyceridemia in Iran is rare. According to the latest results of the ongoing Tehran Lipid and Glucose Study (TLGS), $37.6 \%$ of Tehranian adolescents (age: 10-19 years) have TG levels above $110 \mathrm{mg} / \mathrm{dl}$, defined as hypertriglyceridemia for their age range [53]. We estimated the prevalence of hypertriglyceridemia to be $36.4 \%$ among Iranian adults (33.2\% in females and $39.6 \%$ in males). The figure is $30 \%$ in the US (age $\geq 20$ years) [43], 25\% in Sweden (age: $45-69$ years) [54], 19.2\% in Italy (age $\geq 20$ years) [55], 12.5\% in Switzerland (age: 35-75 years) [56] and approximately $18 \%$ in Portugal (age: $30-70$ years) [57]. Our estimate is higher than the mentioned western countries. Similar reports from Saudi Arabia $(40.3 \% ; 33.7 \%$ in females and $47.6 \%$ in males) [58], Turkey $(30.7 \% ; 26.1 \%$ in females and $36.2 \%$ in males) [44] and Lebanon (35.3\%; $22.6 \%$ in females and $52.4 \%$ in males) [59] suggest that hypertriglyceridemia is a more common problem in our region than in western countries.

\section{Hypercholesterolemia}

Data from previous reports on the prevalence of hypercholesterolemia in Iran is rare. According to the recent results of TLGS, the mean level of total cholesterol among Tehranian adult females is approximately $200 \mathrm{mg} / \mathrm{dl}$, suggesting that about half of the female population of Tehran suffer from hypercholesterolemia [60]. In our survey, the prevalence of total hypercholesterolemia (TC $\geq 200 \mathrm{mg} /$ dl) was estimated to be $42.9 \%$ (45.4\% in females and $40.4 \%$ in males). In 2005, The American Heart Association (AHA) reported the prevalence of hypercholesterolemia to be $48.2 \%$ (48.6\% in females and $47.8 \%$ in males) in non-Hispanic white Americans aged $\geq 20$ [61]. In UK, approximately $48 \%$ (48\% in females and $48 \%$ in males) of adults aged 19-64 years had hypercholesterolemia [62]. The prevalence rates in these two developed countries, and in a rather similar age range to our study, are approximately only five percent higher than our estimate in a developing country. The prevalence rate in Portugal (56.7\%; age: 30-70 years) [57] and Saudi Arabia (54\%; age: $30-70$ years) [58] is also about $10-15 \%$ higher than our prevalence rate. The difference between the latter two studies and ours of about 5 years in the age range may explain the difference in prevalence rates. Hypercholesterolemia was present in $32.8 \%$ (34.2\% in females and $31.6 \%$ in males) of the Chinese aged 35-74 years [63], which is much lower than our estimates and most of the above countries. The rising trend of hypercholesterolemia with increasing age was observed in all of the above studies. 


\section{Conclusion}

We documented a strikingly high prevalence of a number of chronic non-communicable diseases and their risk factors in Iran, and showed that the prevalence of these metabolic abnormalities in our country, as a developing country in the nutritional and life style transition phase is comparable, if not higher, to most developed countries. With continuation and acceleration of urbanization, the prevalence of these disease conditions will likely escalate. Therefore, urgent preventive interventions on a national scale should target these highly prevalent metabolic abnormalities (e.g. diabetes, obesity, hypertension, and dyslipidemia). Based on our results, women and urban residents need to be the focus of more intensive attention. The main limitation with our study was the possibility of recall bias associated with questions regarding past medical history (e.g. diabetes, hypertension). The other limitation of our results stems from the fact that approximately one fifth of our participants did not consent to blood sampling. Since only the demographic and anthropometric characteristics of these individuals were analyzed, additional sources of bias might have affected our results. Finally, caution needs to be practiced in inter-country comparisons which are subject to misinterpretations due to differences in age groups, study design, sampling method, and the year in which each survey was carried out.

\section{Competing interests}

The authors declare that they have no competing interests.

\section{Authors' contributions}

AE provided clinical expertise throughout the project. AM supervised the analysis and manuscript preparation. OK performed the statistical analysis and drafted the manuscript. AR contributed to the literature review, and helped with the revized manuscript. $\mathrm{MH}$ participated in the design and coordination of the survey. FA and MMG conducted the survey. MK cooperated in drafting the manuscript. MA designed the manuscript structure and contributed to the writing. All authors read and approved the final manuscript draft.

\section{Acknowledgements}

This study was supported by the Center for Disease Control, Ministry of Health and Medical education, Tehran, Iran.

\section{References}

I. Yach D, Hawkes C, Gould CL, Hofman KJ: The global burden of chronic diseases: overcoming impediments to prevention and control. JAMA 2004, 29I(2I):26I6-2622.

2. WHO: Preventing Chronic Diseases: a Vital Investment: WHO Global Report Geneva: World Health Organization; 2005.

3. Abegunde DO, Mathers CD, Adam T, Ortegon M, Strong K: The burden and costs of chronic diseases in low-income and middle-income countries. Lancet 2007, 370(9603):1929-1938.

4. Murray CJ, Lopez AD: Alternative projections of mortality and disability by cause 1990-2020: Global Burden of Disease Study. Lancet 1997, 349(9064): I498-1504.
5. Boutayeb A, Boutayeb S: The burden of non communicable diseases in developing countries. Int J Equity Health 2005, 4(I):2.

6. Beaglehole R, Yach D: Globalisation and the prevention and control of non-communicable disease: the neglected chronic diseases of adults. Lancet 2003, 362(9387):903-908.

7. Lopez AD, Mathers CD, Ezzati M, Jamison DT, Murray CJ: Global and regional burden of disease and risk factors, 200 I: systematic analysis of population health data. Lancet 2006, 367(9524): I747-I757.

8. Boutayeb A: The double burden of communicable and noncommunicable diseases in developing countries. Trans $R$ Soc Trop Med Hyg 2006, I00(3): I91-199.

9. Lopez AD, Mathers CD: Measuring the global burden of disease and epidemiological transitions: 2002-2030. Ann Trop Med Parasitol 2006, 1 00(5-6):481-499.

10. Woodward M, Barzi F, Martiniuk A, Fang X, Gu DF, Imai Y, Lam TH, Pan WH, Rodgers A, Suh I, et al.: Cohort profile: the Asia Pacific Cohort Studies Collaboration. Int J Epidemiol 2006, 35(6): $14 \mid 2-1416$.

II. Asia Pacific Cohort Studies Collaboration: The burden of overweight and obesity in the Asia-Pacific region. Obes Rev 2007, 8(3): $191-196$.

12. Lee CM, Huxley RR, Lam TH, Martiniuk AL, Ueshema H, Pan WH, Welborn T, Woodward M: Prevalence of diabetes mellitus and population attributable fractions for coronary heart disease and stroke mortality in the WHO South-East Asia and Western Pacific regions. Asia Pac J Clin Nutr 2007, I 6(I): I87- 92.

13. Martiniuk AL, Lee CM, Lawes CM, Ueshima H, Suh I, Lam TH, Gu D, Feigin V, Jamrozik K, Ohkubo T, et al: Hypertension: its prevalence and population-attributable fraction for mortality from cardiovascular disease in the Asia-Pacific region. J Hypertens 2007, 25(I):73-79.

14. Woodward M, Martiniuk A, Ying Lee CM, Lam TH, Vanderhoorn S, Ueshima H, Fang X, Kim HC, Rodgers A, Patel A, et al.: Elevated total cholesterol: its prevalence and population attributable fraction for mortality from coronary heart disease and ischaemic stroke in the Asia-Pacific region. Eur J Cardiovasc Prev Rehabil 2008, I 5(4):397-40I.

15. WHO: STEPwise approach to surveillance (STEPS). [http:// www.who.int/chp/steps/en/]. Accessed: I Oct, 2008.

16. Diagnosis and classification of diabetes mellitus. Diabetes Care 2008, 3 I (SuppI I):S55-60.

17. Chobanian AV, Bakris GL, Black HR, Cushman WC, Green LA, Izzo JL Jr, Jones DW, Materson BJ, Oparil S, Wright JT Jr, et al:: The Seventh Report of the Joint National Committee on Prevention, Detection, Evaluation, and Treatment of High Blood Pressure: the JNC 7 report. JAMA 2003, 289( I9):2560-2572.

18. WHO: Obesity: Preventing and Managing the Global Epidemic Geneva, Switzerland: World Health Organization; 1998.

19. International Diabetes Federation: The IDF consensus worldwide definition of the metabolic syndrome [article online]. 2006 [http://www.idf.org/webdata/docs/IDF Meta def final.pdf]. Accessed: I Oct, 2008.

20. Expert Panel on Detection, Evaluation, and Treatment of High Blood Cholesterol in Adults: Executive Summary of The Third Report of The National Cholesterol Education Program (NCEP) Expert Panel on Detection, Evaluation, And Treatment of High Blood Cholesterol In Adults (Adult Treatment Panel III). JAMA 200I, 285( ( 9):2486-2497.

21. Statistical Center of Iran: Population Estimates. [http:// www.sci.org.ir/portal/faces/public/sci/sci.gozide/sci.PopEstimate].

22. Azimi-Nezhad M, Ghayour-Mobarhan M, Parizadeh MR, Safarian M, Esmaeili H, Parizadeh SM, Khodaee G, Hosseini J, Abasalti Z, Hassankhani B, et al.: Prevalence of type 2 diabetes mellitus in Iran and its relationship with gender, urbanisation, education, marital status and occupation. Singapore Med J 2008, 49(7):57|-576.

23. Sadeghi M, Roohafza H, Shirani S, Poormoghadas M, Kelishadi R, Baghaii A, Sarraf-Zadegan N: Diabetes and associated cardiovascular risk factors in Iran: the Isfahan Healthy Heart Programme. Ann Acad Med Singapore 2007, 36(3): I75- I 80.

24. Sadeghi M, Roohafza HR, Kelishadi R: Blood pressure and associated cardiovascular risk factors in Iran: Isfahan Healthy Heart Programme. Med J Malaysia 2004, 59(4):460-467.

25. Galal O: Nutrition-related health patterns in the Middle East. Asia Pac J Clin Nutr 2003, I 2(3):337-343. 
26. Esteghamati A, Gouya MM, Abbasi M, Delavari A, Alikhani S, Alaedin F, Safaie A, Forouzanfar M, Gregg EW: Prevalence of diabetes and impaired fasting glucose in the adult population of Iran: National Survey of Risk Factors for Non-Communicable Diseases of Iran. Diabetes Care 2008, 3 I (I):96-98.

27. Cowie CC, Rust KF, Byrd-Holt DD, Eberhardt MS, Flegal KM, Engelgau MM, Saydah SH, Williams DE, Geiss LS, Gregg EW: Prevalence of diabetes and impaired fasting glucose in adults in the U.S. population: National Health And Nutrition Examination Survey 1999-2002. Diabetes Care 2006, 29(6): | 263-I 268.

28. Forouhi NG, Merrick D, Goyder E, Ferguson BA, Abbas J, Lachowycz $\mathrm{K}$, Wild SH: Diabetes prevalence in England, 200 I - estimates from an epidemiological model. Diabet Med 2006, 23(2): 189-197.

29. Dunstan DW, Zimmet PZ, Welborn TA, De Courten MP, Cameron AJ, Sicree RA, Dwyer T, Colagiuri S, Jolley D, Knuiman M, et al.: The rising prevalence of diabetes and impaired glucose tolerance: the Australian Diabetes, Obesity and Lifestyle Study. Diabetes Care 2002, 25(5):829-834.

30. Onat A, Hergenc G, Uyarel H, Can G, Ozhan H: Prevalence, incidence, predictors and outcome of type 2 diabetes in Turkey. Anadolu Kardiyol Derg 2006, 6(4):3|4-32|

31. Gu D, Reynolds K, Duan X, Xin X, Chen J, Wu X, Mo J, Whelton PK, $\mathrm{He} \mathrm{J}$ : Prevalence of diabetes and impaired fasting glucose in the Chinese adult population: International Collaborative Study of Cardiovascular Disease in Asia (InterASIA). Diabetologia 2003, 46(9): I I 90-I I 98.

32. Kim SM, Lee JS, Lee J, Na JK, Han JH, Yoon DK, Baik SH, Choi DS, Choi KM: Prevalence of diabetes and impaired fasting glucose in Korea: Korean National Health and Nutrition Survey 200I. Diabetes Care 2006, 29(2):226-23I.

33. Ramachandran A, Snehalatha C, Kapur A, Vijay V, Mohan V, Das AK, Rao PV, Yajnik CS, Prasanna Kumar KM, Nair JD: High prevalence of diabetes and impaired glucose tolerance in India: Nationa Urban Diabetes Survey. Diabetologia 200I, 44(9): 1094-II 0 I.

34. Rashidi A, Mohammadpour-Ahranjani B, Vafa MR, Karandish M: Prevalence of obesity in Iran. Obes Rev 2005, 6(3): | $9|-| 92$.

35. Hajian-Tilaki KO, Heidari B: Prevalence of obesity, central obesity and the associated factors in urban population aged 20 70 years, in the north of Iran: a population-based study and regression approach. Obes $\operatorname{Rev} 2007,8(1): 3-10$.

36. Ogden CL, Yanovski SZ, Carroll MD, Flegal KM: The epidemiology of obesity. Gastroenterology 2007, I 32(6):2087-21 02

37. Australian Institute of Health and Welfare: Australia's Health 2006: the tenth biennial health report of Australian Institute of Health and Welfare. [http://www.aihw.gov.au/publications/aus/ ah06/ah06.pdf].

38. The NHS Information Center: Health Survey for England 2006: Latest Trends. [http://www.ic.nhs.uk/webfiles/publications/HSE06/ Health Survey for England 2006 Latest Trends.pdf].

39. al-Nuaim AR, al-Rubeaan $\mathrm{K}$, al-Mazrou $\mathrm{Y}$, al-Attas $\mathrm{O}$, al-Daghari $\mathrm{N}$, Khoja T: High prevalence of overweight and obesity in Saudi Arabia. Int J Obes Relat Metab Disord 1996, 20(6):547-552.

40. Al-Lawati JA, Jousilahti PJ: Prevalence and 10 -year secular trend of obesity in Oman. Saudi Med J 2004, 25(3):346-35I.

4I. Sibai AM, Hwalla N, Adra N, Rahal B: Prevalence and covariates of obesity in Lebanon: findings from the first epidemiological study. Obes Res 2003, I I(II): I353-I36I.

42. Yumuk VD: Prevalence of obesity in Turkey. Obes Rev 2005 6(1):9-10.

43. Ford ES, Giles WH, Dietz WH: Prevalence of the metabolic syndrome among US adults: findings from the third National Health and Nutrition Examination Survey. JAMA 2002, 287(3):356-359.

44. Erem C, Hacihasanoglu A, Deger O, Topbas M, Hosver I, Ersoz HO, Can G: Prevalence of metabolic syndrome and associated risk factors among Turkish adults: Trabzon MetS study. Endocrine 2008, 33(I):9-20.

45. Bouguerra R, Ben Salem L, Alberti H, Ben Rayana C, El Atti J, Blouza S, Gaigi S, Achour A, Ben Slama C, Zouari B: Prevalence of metabolic abnormalities in the Tunisian adults: a population based study. Diabetes Metab 2006, 32(3):215-22I.

46. Gu D, Reynolds K, Wu X, Chen J, Duan X, Reynolds RF, Whelton PK, $\mathrm{He} \mathrm{J}$ : Prevalence of the metabolic syndrome and overweight among adults in China. Lancet 2005, 365(9468):|398-| 405.
47. Park HS, Kim SM, Lee JS, Lee J, Han JH, Yoon DK, Baik SH, Choi DS, Choi KM: Prevalence and trends of metabolic syndrome in Korea: Korean National Health and Nutrition Survey 1998200I. Diabetes Obes Metab 2007, 9(I):50-58.

48. Esteghamati A, Abbasi M, Alikhani S, Gouya MM, Delavari A, Shishehbor MH, Forouzanfar M, Hodjatzadeh A, Ramezani RD: Prevalence, awareness, treatment, and risk factors associated with hypertension in the Iranian population: the national survey of risk factors for noncommunicable diseases of Iran. Am J Hypertens 2008, 21 (6):620-626.

49. Kearney PM, Whelton M, Reynolds K, Whelton PK, He J: Worldwide prevalence of hypertension: a systematic review. J Hypertens 2004, 22(1): II-19.

50. Altun B, Arici M, Nergizoglu G, Derici U, Karatan O, Turgan C, Sindel S, Erbay B, Hasanoglu E, Caglar S: Prevalence, awareness, treatment and control of hypertension in Turkey (the Paten T study) in 2003. J Hypertens 2005, 23(10): |8|7-1823.

5I. Wolf-Maier K, Cooper RS, Banegas JR, Giampaoli S, Hense HW, Joffres M, Kastarinen M, Poulter N, Primatesta P, Rodriguez-Artalejo F, et al:: Hypertension prevalence and blood pressure levels in 6 European countries, Canada, and the United States. JAMA 2003, 289(18):2363-2369.

52. Gu D, Reynolds K, Wu X, Chen J, Duan X, Muntner P, Huang G, Reynolds RF, Su S, Whelton PK, et al:: Prevalence, awareness, treatment, and control of hypertension in china. Hypertension 2002, 40(6):920-927.

53. Esmaillzadeh A, Mirmiran P, Azizi F: Clustering of metabolic abnormalities in adolescents with the hypertriglyceridemic waist phenotype. Am J Clin Nutr 2006, 83(I):36-46

54. Hollman G, Kristenson M: The prevalence of the metabolic syndrome and its risk factors in a middle-aged Swedish population - mainly a function of overweight? Eur J Cardiovasc Nurs 2008, 7(I):2I-26

55. Miccoli R, Bianchi C, Odoguardi L, Penno G, Caricato F, Giovannitti MG, Pucci L, Del Prato S: Prevalence of the metabolic syndrome among Italian adults according to ATP III definition. Nutr Metab Cardiovasc Dis 2005, I 5(4):250-254.

56. Firmann M, Mayor V, Vidal PM, Bochud M, Pecoud A, Hayoz D, Paccaud F, Preisig M, Song KS, Yuan X, et al.: The CoLaus study: a population-based study to investigate the epidemiology and genetic determinants of cardiovascular risk factors and metabolic syndrome. BMC Cardiovasc Disord 2008, 8:6.

57. Costa J, Borges M, Oliveira E, Gouveia M, Carneiro AV: Incidence and prevalence of hypercholesterolemia in Portugal: a systematic review. Part III. Rev Port Cardiol 2003, 22(6):829-836.

58. Al-Nozha MM, Arafah MR, Al-Maatouq MA, Khalil MZ, Khan NB, AlMarzouki K, Al-Mazrou YY, Abdullah M, Al-Khadra A, Al-Harthi SS, et al.: Hyperlipidemia in Saudi Arabia. Saudi Med I 2008 , 29(2):282-287

59. Sibai AM, Obeid OA, Batal M, Adra N, Dit El Khoury DT, Hwalla N: Prevalence and correlates of metabolic syndrome in an adult Lebanese population. Prev Control 2008, 3:83-90.

60. Ainy E, Azizi F: Women, occupation and cardiovascular risk factors: findings from the Tehran Lipid and Glucose Study. Public Health 2007, I 2 I ( I 2):950-953.

6I. Rosamond W, Flegal K, Furie K, Go A, Greenlund K, Haase N, Hailpern SM, Ho M, Howard V, Kissela B, et al: Heart disease and stroke statistics - 2008 update: a report from the American Heart Association Statistics Committee and Stroke Statistics Subcommittee. Circulation 2008, II 7(4):e25-I46.

62. United Kingdom Food Standard Agency: The National Diet \& Nutrition Survey: adults aged 19 to 64 years (Summary Report). [http://www.food.gov.uk/multimedia/pdfs/ndns5full.pdf].

63. He J, Gu D, Reynolds K, Wu X, Muntner P, Zhao J, Chen J, Liu D, Mo J, Whelton PK: Serum total and lipoprotein cholesterol levels and awareness, treatment, and control of hypercholesterolemia in China. Circulation 2004, I I 0(4):405-4II.

\section{Pre-publication history}

The pre-publication history for this paper can be accessed here:

http://www.biomedcentral.com/1471-2458/9/167/pre

pub 